\title{
Pengaruh Model Inkuiri Terbimbing dengan Alat Peraga Barbeku terhadap Pemahaman Konsep Siswa pada Materi Hukum Newton
}

\author{
Chairatul Umamah ${ }^{1)^{*}}$, Herman Jufri Andi ${ }^{1),}$, Sitti Aisah ${ }^{1)}$ \\ ${ }^{1)}$ Universitas Islam Madura, Indonesia \\ *chairatul.physics@gmail.com
}

Abstrak: Penelitian ini bertujuan mengidentifikasi dan mendeskripsikan pengaruh signifikansi antara model pembelajaran inkuiri terbimbing dengan alat peraga barbeku dibandingkan dengan model pembelajaran konvensional terhadap pemahaman konsep fisika siswa. Penelitian yang digunakan adalah quasi experiment dengan bentuk desain eksperimen pretest-posttest control group design. Populasinya adalah kelas X MA AlIslamiyah 1 Blumbungan dengan sampel sebanyak dua kelas yang diperoleh dari purposive sampling. Instrumen yang digunakan dalam penelitian ini yaitu berupa Tes Pemahaman Konsep, Instrument Silabus, RPP, Lembar Kerja Siswa, Pretest dan Posttest. Berdasarkan hasil penelitian, dapat diketahui bahwa nilai pretest - posttest pada kelas kontol 27,27 dan 55,45 sedangkan nilai pretest - posttest pada kelas eksperimen 20.91 dan 81,36. Hasil uji normalitas menggunakan uji Shapiro-wilk diketahui bahwa nilai signifikan pretest posttest pada kelas kontrol dan kelas eksperimen berdistribusi normal dengan nilai signifikan > 0,05. Berdasarkan hasil uji hipotesis menggunakan uji independent sampel t-test dengan bantuan spss versi 25 diperoleh data thitung sebesar 6,751 dan signifikansi 0,000. Dari perhitungan tersebut dapat diketahui bahwa thitung $>$ tabel, karena nilai thitung $=6,751$ dan nilai ttabel $=0,000$. Mengacu pada dasar pengambilan keputusan dalam uji independent sampel t-test, jika nilai sig (2-tailed) < 0,05 maka HO ditolak dan Ha diterima.

Kata Kunci: Model Pembelajaran Inkuiri Terbimbing, Alat Peraga BARBEKU, Pemahaman Konsep.

\section{PENDAHULUAN}

Fisika merupakan salah satu mata pelajaran yang terdiri dari berbagai konsep yang sangat dekat dengan kehidupan sehari-hari. Sehingga pemahaman konsep sangat dibutuhkan dalam proses pembelajaran. Hal ini agar tujuan Pendidikan, seperti memfasilitasi siswa untuk memperoleh pemahaman konsep yang baik (Gardner, 1999) dapat tercapai dengan baik. Pemahaman konsep yang baik dapat membuat siswa mampu mengungkapkan makna dari suatu konsep, membedakan dan menjelaskan suatu objek yang didasarkan pada ciri-ciri yang dimiliki oleh objek itu sendiri, serta mengerti karakteristik suatu materi yang menjadi dasar siswa membangun wawasan dalam proses pembelajaran (Arends, 2012). Pemahaman konsep yang juga merupakan bagian dari kemampuan berpikir tingkat tinggi menjadi landasan untuk memperoleh kemampuan pemecahan masalah, berpikir kritis, dan berpikir relatif siswa (Bern \& Erickson, 2001). Dalam pembelajaran fisika, pemahaman konsep merupakan syarat keberhasilan dalam belajar yang dapat membantu siswa meminimalisir miskonsepsi (Siahaan et al., 2020). Dengan demikian jika siswa mampu membangun pemahaman konsep dengan baik, Siswa dapat menyelesaikan permasalahan-permasalahan fisika dengan mudah (Herimanto et al., 2018).

Berdasarkan hasil dari observasi dan wawancara terhadap guru mata pelajaran fisika di salah satu sekolah MA di Pamekasan, ditemukan adanya kendala dalam pemahaman konsep fisika pada materi Hukum Newton di sekolah tersebut. Berdasarkan hasil wawancara dengan beberapa siswa kelas X di sekolah tersebut ditemukan kendala juga yang berasal dari sudut pandang siswa seperti siswa merasa sulit dalam memahami konsep dan rumus fisika pada materi Hukum Newton, siswa merasa sulit dalam mengerjakan soal fisika pada materi Hukum Newton, dan siswa merasa jenuh dalam pembelajaran fisika karena metode yang digunakan oleh guru tidak bervariasi hanya metode ceramah saja dan tidak melibatkan siswa berperan aktif dalam pembelajaran. Hal tersebut tentunya menyebabkan pemahaman konsep siswa pada materi Hukum Newton masih berada di bawah Kriteria Ketuntasan Minimum (KKM) yang diharapkan yaitu 85\% dari seluruh siswa 
kelas X dengan skor minimum 75. Dengan kendala-kendala yang dialami tersebut, perlu dilakukan perubahan paradigm dan metode pembelajaran yang berorientasi pada siswa sehingga pembelajaran tidak berjalan monoton, siswa dapat berperan aktif, dan siswa dapat memahami konsep materi Hukum Newton dengan baik dan menyenangkan.

Untuk memperoleh pola pembelajaran yang berkualitas diperlukan model pembelajaran yang efektif, yang lebih menekankan pada proes dari pada penekanan pada hasil. Hal tersebut sesuai dengan Bruner dalam (Trianto, 2011) yang menyatakan bahwa pembelajaran penemuan menekankan pada keterlibatan siswa secara aktif, pengalaman-pengalaman belajar memusat pada siswa, dimana siswa menemukan ide-ide dan merumuskan makna belajar untuk mereka sendiri. Pembelajaran inkuiri terbimbing merupakan suatu model pembelajaran inkuiri yang dalam pelaksanaanya guru menyediakan bimbingan atau petunjuk cukup luas kepada siswa (Suyanti, 2010). Serta model pembelajaran inkuiri terbimbing adalah model pembelajaran yang mengharuskan siswa membangun sendiri pengetahuan di dalam benaknya. Guru dapat memberikan kemudahan untuk proses ini, dengan memberi kesempatan kepada siswa untuk menemukan atau menerapkan ide-ide sendiri, dan mengajar siswa menjadi sadar dan secara sadar menggunakan strategi mereka sendiri untuk belajar (Trianto, 2011). Salah satu cara untuk membantu siswa membangun pengetahuan mereka sendiri dalam proses pembelajaran, guru harus menggunakan media pembelajaran.

Penggunaan media pembelajaran dapat membantu dalam menyampaikan materi pelajaran apalagi dengan keterbatasan waktu guru mengajar, dengan media pembelajaran bab pelajaran yang tergolong banyak dapat dijelaskan dalam satu kemasan seperti alat peraga. Menurut Fitriana, (2020), fungsi media pembelajaran dalam proses belajar mengajar yaitu untuk meningkatkan rangsangan peserta didik dalam kegiatan belajar. Sehingga peneliti merasa perlu adanya bantuan media pembelajaran yang dalam penelitian ini menggunakan alat peraga BARBEKU (Barang Bekas Di Sekitarku) untuk mendukung model pembelajaran inkuiri terbimbing. Menurut Masturoh (2019), Alat peraga BARBEKU merupakan alat peraga yang memanfaatkan bahan-bahan bekas atau barang-barang yang mudah kita temukan disekitar lingkungan kita. Dengan demikian siswa dapat dengan mudah memahami suatu konsep fisika, karena fisika ada disekitar mereka.

Berdasarkan latar belakang diatas, maka tujuan dari penelitian ini adalah: 1 Untuk mengetahui ada atau tidaknya pengaruh yang signifikan dalam penggunaan model inkuiri terbimbing dengan alat peraga BARBEKU terhadap pemahaman konsep siswa pada materi hukum newton. 2) Untuk mengetahui seberapa besar peningkatan pemahaman konsep siswa pada materi hukum newton setelah menggunakan model inkuiri terbimbing dengan alat peraga BARBEKU.

\section{METODE}

Metode penelitian yang digunakan dalam penelitian ini adalah metode quasi eksperimen (eksperimen semu). Desain yang digunakan adalah pretes-postest control group design, yang terdiri dari dua kelompok penelitian yaitu kelas eksperimen (kelas perlakuan), kelas ini merupakan kelompok siswa yang pembelajaran eksperimennya menggunakan model pembelajaran inkuiri terbimbing berbantuan alat peraga BARBEKU dan kelas kontrol (kelas pembanding) adalah kelompok siswa yang pembelajarannya menggunakan model pembelajaran konvensional. Selanjutnya, setelah proses pembelajaran selesai diberikan tes kepada dua kelas. Bagan desain penelitian pretes-postes control group design sebagai berikut:

$$
\begin{aligned}
& \mathrm{O}_{1} \rightarrow \mathrm{X}_{1} \rightarrow \mathrm{O}_{2} \\
& \mathrm{O}_{1} \rightarrow \mathrm{X}_{2} \rightarrow \mathrm{O}_{2} \\
& \text { (Sugiono, 2017) }
\end{aligned}
$$

\section{Keterangan:}

O1 : Tes awal yang diberikan pada kelas eksperimen dan kelas kontrol sebelum diberi perlakuan pada awal penelitian.

O2 : Tes akhir yang diberikan pada kelas eksperimen dan kelas kontrol setelah diberi perlakuan diakhir penelitian.

X1 : Perlakuan yang diberikan pada kelas eksperimen yaitu kegiatan pembelajarannya menggunakan model pembelajaran inkuiri terbimbing dengan alat peraga BARBEKU.

X2 : Perlakuan pada kelas kontrol menggunakan model konvensional. 
Penelitian ini dilakukan untuk mengetahui adanya pengaruh yang signifikan model pembelajaran inkuiri terbimbing dengan alat peraga barbeku terhadap pemahaman konsep fisika siswa pada materi Hukum Newton pada kelas eksperimen dan kelas kontrol. Kelas X IPA C sebagai kelas kontrol dan X IPA B sebagai kelas eksperimen di MA Miftahul Ulum Bettet Pamekasan. Perbedaan perlakuan yang antara kedua kelas terletak pada penggunaan model pembelajaran, yaitu model pembelajaran inkuiri terbimbing dengan alat peraga brbeku diterapkan pada kelas eksperimen sedangkan pada kelas kontrol diterapkan model konvensional.

Data yang dikumpulkan dalam penelitian ini adalah data pemahaman konsep siswa dengan teknik pengumpulan data yang digunakan adalah teknik tes berupa pretest-posttest dan observasi pada keterlaksanaan pembelajaran. Pretest dilakukan untuk mengukur kemampuan awal siswa sebelum diberikan perlakuan. Selanjutnya dilakukan tes akhir berupa posttest untuk mengetahui seberapa besar perubahan yang dialami siswa dalam peningkatan pemahaman konsep siswa setelah diberikan perlakuan. Metode observasi merupakan cara pengumpulan data dengan melakukan pengamatan yang meliputi keterlaksanaan Rencana Pelaksanaan Pembelajaran (RPP) oleh pengamat atau observer.

Teknik analisis data yang digunakan untuk menjawab rumusan masalah adalah independent sample ttest dan uji N-gain menggunakan aplikasi SPSS versi 25. Pertama, data diuji normalitas menggunakan uji Shapiro-wilk dengan SPSS versi 25 untuk mengetahui data berdistribusi normal. Setelah data terbukti normal, maka dilakukan uji homogenitas menggunakan aplikasi SPSS versi 25 untuk mengetahui kehomogenitasan kedua sampel. Setelah data terbukti normal dan homogen, selanjutnya dilakukan uji hipotesis menggunakan independent sample t-test dengan SPSS versi 25. Hipotesis statistik yang digunakan yaitu:

Hipotesis Nihil $(\mathrm{HO})=$ Tidak terdapat pengaruh yang signifikan pada pemahaman konsep siswa setelah menggunakan model inkuiri terbimbing dengan alat peraga BARBEKU

Hipotesis Alternatif $(\mathrm{H} 1)=$ Terdapat pengaruh yang signifikan pada pemahaman konsep siswa setelah menggunakan model inkuiri terbimbing dengan alat peraga BARBEKU

Dasar pengambilan keputusan dalam uji Independent Sample T-test berdasarkan kriteria pengujian (Jaya, 2010) yaitu:

Jika nilai $t_{\text {hitung }}>t_{\text {tabel }}$, maka HO ditolak dan $\mathrm{H} 1$ diterima.

Jika nilai $t_{\text {hitung }}<t_{\text {tabel}}$, maka HO diterima dan H1 ditolak.

Pengambilan keputusan juga dapat dilihat dengan menggunakan kriteria pengujian berdasarkan probabilitas (Saragih, 2015), yakni:

Jika nilai signifikan (2-tailed) <0,05, maka HO ditolak dan H1 diterima.

Jika nilai signifikan (2-tailed) > 0,05, maka HO diterima dan H1 ditolak.

Sedangkan untuk uji $\mathrm{N}$-gain, peningkatan hasil belajar fisika SMA dapat dikategorikan sebagai berikut:

Tabel 1 Kategori nilai N-gain

\begin{tabular}{cc}
\hline Nilai N-Gain & Kategori \\
\hline$G>0,7$ & Tinggi \\
$0,3 \leq G \leq 0,7$ & Sedang \\
$G<0,3$ & Rendah \\
\hline
\end{tabular}

\section{HASIL DAN PEMBAHASAN}

Hasil

Penelitian ini melibatkan dua kelompok penelitian yaitu kelompok eksperimen pada kelas X IPA B dan kelompok kontrol pada kelas X IPA C. Kelas eksperimen menggunakan model inkuiri terbimbing dengan alat peraga BARBEKU dan kelas kontrol menggunakan model konvensial. Dalam penelitian ini, peneliti memperoleh data dari hasil pretest dan posttest yang dilakukan pada kelas eksperimen (X-IPA B) dan kelas kontrol (X-IPA C). Pengambilan data dilakukan dengan memberikan soal pretest terlebih dahulu pada kelas 
eksperimen dan kelas kontrol. Kemudian peneliti memberikan perlakuan dengan menerapkan model pembelajaran inkuiri terbimbing dengan alat peraga barbeku pada eksperimen dan menggunakan model konvensional pada kelas kontrol. Setelah diberi perlakuan, peneliti melakukan tes akhir (posttest) pada kelas eksperimen dan kelas kontrol. Hal ini dilakukan untuk mengetahui kemampuan akhir siswa setelah diberi perlakuan. Kemudian dilakukan uji prasyarat yaitu uji normalitas dan uji homogentias untuk mengetahui bahwa data yang diperoleh terdistribusi normal atau tidak dan untuk mengetahui data tersebut homogen atau tidak homogen. Data yang sudah terdistribusi normal dan homogen akan dilanjutkan dengan uji hipotesis dan uji N-Gain.

\section{Data Pemahaman Konsep Pretest Dan Posttes Siswa}

Ringkasan data nilai hasil pemahaman konsep siswa diperoleh berdasarkan hasil pretest dan posttest yang dilakukan pada kedua kelas yaitu kelas X IPA B dengan model inkuiri terbimbing dengan alat peraga barbeku dan XI IPA C dengan model konvensional. Deskripsi data pemahaman konsep dapat dibaca pada table 2 berikut:

Table 2 Data pemahaman konsep pretest dan posttes siswa

\begin{tabular}{cccccc}
\hline & \multicolumn{6}{l}{ Data Pemahaman Konsep Pretest dan Posttes Siswa } \\
\hline & $\mathrm{N}$ & Minimum & Maximum & Mean & Std. Deviation \\
\cline { 2 - 6 } PreEks & 22 & 0 & 50 & 20.91 & 14.111 \\
PostEks & 22 & 50 & 100 & 81.36 & 13.904 \\
PreKon & 22 & 10 & 50 & 27.27 & 11.622 \\
PostKon & 22 & 30 & 80 & 55.45 & 11.434 \\
Valid N (listwise) & 22 & & & & \\
\hline
\end{tabular}

Pada tabel dapat terlihat jelas perbedaan nilai rata-rata pretest dan posttest kelas kontrol dan kelas eksperimen. Pada kelas kontrol nilai rata-rata pretest $=27,27$ dan posttest $=55,45$, serta pada kelas eksperimen nilai rata-rata pretest $=20,91$ dan posttest $=81,36$.

\section{Uji Normalitas}

Uji normalitas dilakukan untuk menguji apakah semua variabel berdistribusi normal atau tidak. Uji normalitas menggunakan rumus Shapiro-Wilk dalam perhitungan menggunakan program SPSS versi 25. untuk mengetahui normal tidaknya adalah jika sig $>0,05$ maka normal dan jika sig < 0,05 dapat dikatakan tidak normal. Ringkasan hasil perhitungan yang diperoleh sebagai berikut:

Table 3 Ringkasan hasil uji normalitas pemahaman konsep

\begin{tabular}{lcccc}
\hline & \multicolumn{3}{c}{ Tests of Normality } & \multicolumn{3}{c}{ Shapiro-Wilk } \\
\cline { 2 - 5 } & Kelas & Statistic & Df & Sig. \\
\cline { 2 - 5 } Pemahaman konsep siswa & PreEks & .924 & 22 & .094 \\
& PostEks & .920 & 22 & .078 \\
& PreKon & .915 & 22 & .061 \\
& PostKon & 920 & 22 & .075 \\
\hline
\end{tabular}

Berdasarkan Tabel 3 diketahui bahwa Hasil Shapiro-Wilk menunjukan data pemahaman konsep siswa untuk kelas kontrol, terdistribusi secara normal. Pada pretest kelas kontrol diperoleh nilai sig 0,061 artinya nilai sig SPSS > nilai signifikannya $\alpha(0.061>0,05)$ sehingga data terdistribusi normal, dan posttest kelas kontrol diperoleh nilai sig 0,075 artinya nilai sig SPSS > nilai signifikannya $\alpha(0,075>0,05)$ sehingga data terdistribusi normal. Pada prettest kelas eksperimen dengan nilai sig 0,094 artinya nilai sig SPSS > nilai signifikannya $\alpha(0,094>0,05)$ sehingga data terdistribusi normal, dan Pada posttes kelas eksperimen dengan nilai sig 0,078 artinya nilai sig SPSS > nilai signifikannya $\alpha(0,078>0,05)$ sehingga data terdistribusi normal. Dari hasil analisis ini dapat disampaikan bahwa hasil penetapan hipotesis stastik adalah HO diterima atau sebaran data setiap kelompok berdistribusi normal sehingga analisis data dapat di lanjutkan pada uji homogenitas. 


\section{Uji Homogenitas}

Setelah diketahui tingkat kenormalan data, maka selanjutnya dilakukan uji homogenitas. Uji homogenitas digunakan untuk mengetahui tingkat kesamaan varians antara dua kelompok yaitu kelompok eksperimen dan kelompok kontrol. Homogenitas varian diuji dengan menggunakan tes of homogenity of variances ringkasan uji homogenitas varian tertera dalam tabel 4 berikut:

Table 4 Ringkasan uji homogenitas pemahaman konsep

\begin{tabular}{|c|c|c|c|c|c|}
\hline \multicolumn{6}{|c|}{ Test of Homogeneity of Variances } \\
\hline \multirow{5}{*}{$\begin{array}{c}\text { Pemahaman } \\
\text { konsep }\end{array}$} & & Levene Statistic & df1 & $\mathrm{df2}$ & Sig. \\
\hline & Based on Mean & 1.342 & 1 & 42 & .253 \\
\hline & Based on Median & 1.566 & 1 & 42 & .218 \\
\hline & Based on Median and with adjusted df & 1.566 & 1 & 40.992 & .218 \\
\hline & Based on trimmed mean & 1.429 & 1 & 42 & .239 \\
\hline
\end{tabular}

Berdasarkan tabel 4 diketahui bahwa hasil pengujian homogenitas data penelitian ini dapat diketahui dengan melihat nilai signifikan pada kolom based on mean yaitu sig $=0,253$. Mengacu pada dasar pengambilan keputusan dalam uji homogenitas maka nilai signifikan $=0,253>0,05$ sehingga HO diterima atau data penelitian homogen. Dengan demikian data penelitian pada kelas kontrol dan kelas eksperimen berdistribusi normal atau homogen, sehingga analisis data penelitian ini dapat dilanjutkan pada tahap uji hipotesis.

\section{Uji Hipotesis}

Uji hipotesis dilakukan setelah semua uji prasyarat terpenuhi, baik uji nomalitas dan homogenitas. Berdasarkan uji normalitas dan homogenitas diketahui bahwa data berdistribusi normal dan homogen, maka untuk uji hipotesisnya menggunakan uji Independent sample t-test dengan bantuan program SPSS versi 25. Pengujian hipotesis pada penelitian ini bertujuan untuk menguji hipotesis yang menyatakan adanya pengaruh model pembelajaran inkuiri terbimbing dengan alat peraga barbeku terhadap pemahaman konsep fisika SMA. Hasil penghitungan uji hipotesis dengan menggunakan program SPSS versi 25 dapat dibaca pada tabel 5 berikut:

Table 5 Hasil Uji Hipotesis Pemahaman Konsep

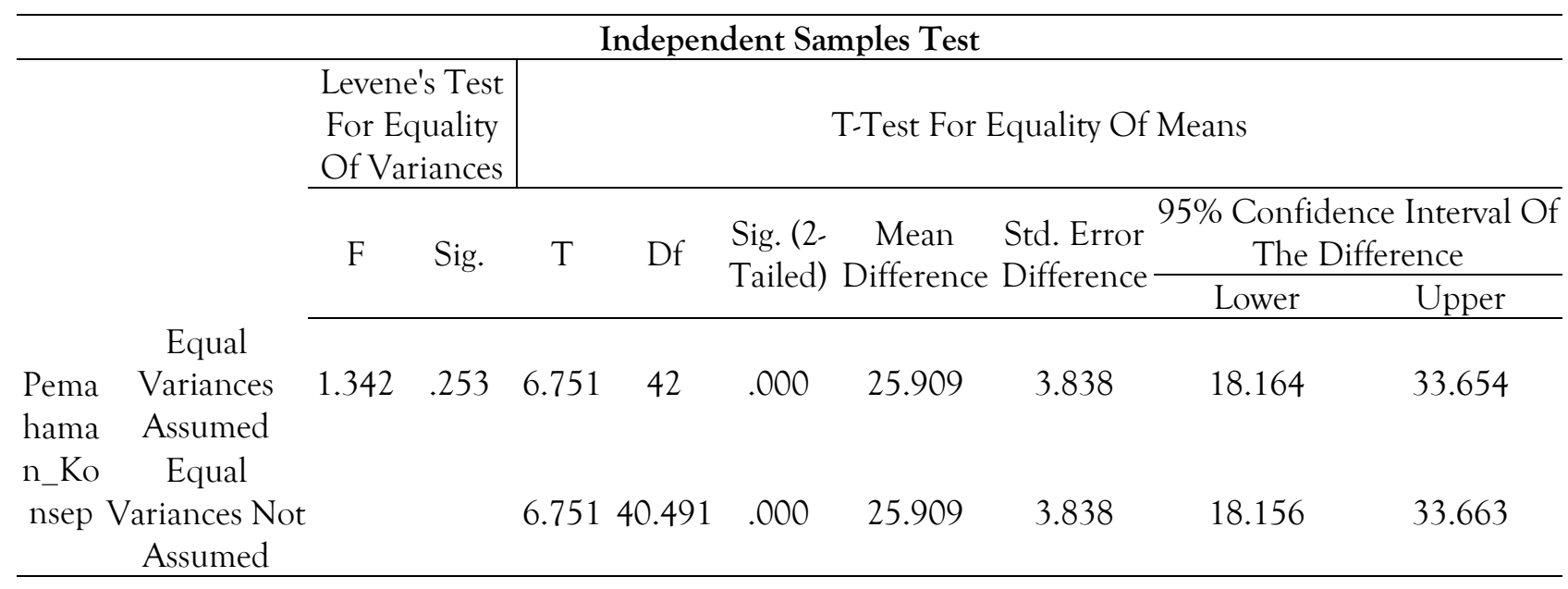

Sebelumnya sudah diketahui bahwa data homogen, maka dapat dibaca data pada kolom Equal variances assumed. Jika sebelumnya data tidak homogen, maka dapat dibaca data pada kolom Equal variances not assumed. Berdasarkan tabel 5, pada kolom Equal variances assumed diatas dapat diketahui bahwa nilai thitung $=6.751$ dan signifikansi 0,000. Dari perhitungan tersebut dapat diketahui bahwa thitung $>$ ttabel atau signifikansi $<0,05$. Karena nilai thitung $=6.751$ dan nilai ttabel $=0,000$, maka $6.751>0,000$. Nilai signifikansi yang diperoleh $=0,000$ maka 0,000 $<0,05$. Mengacu pada dasar pengambilan keputusan dalam uji Independent Sample T-test, maka sig (2-tailed) <0,05 sehingga HO ditolak dan H1 diterima. 


\section{Uji N-Gain}

Perhitungan nilai N-Gain digunakan untuk mengetahui besarnya peningkatan pemahaman konsep siswa pada kelas kontrol dan kelas eksperimen. Perhitungan nilai N-Gain dilakukan dengan menggunakan program SPSS Versi 25 yang hasil perhitungannya adalah sebagai berikut:

Table 6 Ringkasan hasil perhitungan N-Gain

\begin{tabular}{cccccc}
\hline \multicolumn{6}{c}{ h Group Statistics } \\
\hline \multirow{4}{*}{ N-Gain $(\mathrm{g})$} & Variable & $\mathrm{N}$ & Mean & Std. Deviation & Std. Error Mean \\
\cline { 2 - 6 } & Kontrol & 22 & 0,3885 & 0,11021 & 0,02350 \\
& Eksperimen & 22 & 0,7655 & 0,18676 & 0,03982 \\
\hline
\end{tabular}

Berdasarkan tabel 6 dapat diketahui bahwa $\mathrm{g}=0,3885$ dengan $0,3 \leq \mathrm{g}<0,7$ maka peningkatan hasil belajar siswa pada kelas kontrol dapat dikategorikan sedang. Sedangkan pada kelas eksperimen diketahui bahwa $\mathrm{g}=0,7655$, dengan $\mathrm{g} \geq 0,7$ maka peningkatan hasil belajar fisika SMA pada kelas eksperimen dapat dikategorikan tinggi.

Melalui perhitungan tersebut maka dapat ditarik kesimpulan bahwa kelas eksperimen dengan penerapan model inkuiri terbimbing dengan alat peraga barbeku lebih efektif dari pada penerapan model konvensional pada kelas kontrol untuk meningkatkan pemahaman konsep fisika SMA.

\section{Pembahasan}

Penelitian ini dilakukan untuk mengetahui pengaruh model pembelajaran inkuiri terbimbing dengan alat peraga barbeku terhadap pemahaman konsep fisika siswa pada materi Hukum Newton pada kelas eksperimen dan kelas kontrol. Kelas X IPA B sebagai kelas eksperimen sedangkan kelas X IPA C sebagai kelas kontrol. Letak perbedaan antara kedua kelas tersebut adalah penggunaan model pembelajaran. Pada kelas eksperimen, model pembelajaran yang digunakan adalah model pembelajaran inkuiri terbimbing dengan alat peraga barbeku. Sedangkan pada kelas kontrol, model pembelajaran yang digunakan adalah model konvensional.

Penelitian ini menggunakan metode tes untuk mengetahui hasil pemahaman konsep fisika siswa. Kedua kelas diberikan tes awal (pretest) sebelum diberikan perlakuan dan tes akhir (posttest) setelah diberikan perlakuan. Berdasarkan hasil pretest kelas kontrol dan kelas eksperimen diperoleh nilai rata-rata masing-masing kelas sebesar 27,27 dan 20,91, nilai ini dikatakan cukup rendah dibandingkan nilai maksimal (100). Hal tersebut dikarenakan kedua kelas kurang memahami pelajaran fisika pada materi Hukum Newton sebelumnya, sehingga siswa kesulitan untuk mengerjakan soal pretest yang diberikan.

Setelah didapatkan nilai pretest, kedua kelas diberikan perlakuan berupa model konvensional pada kelas kontrol dan model pembelajaran inkuiri terbimbing dengan alat peraga barbeku pada kelas eksperimen dan kemudian diberikan tes akhir (posttest). Hasil posttest menunjukkan adanya perubahan nilai pada kedua kelas, yaitu nilai rata-rata 55,45 pada kelas kontrol dan 81,36 pada kelas eksperimen. Hal ini dikarenakan, saat percobaan berlangsung siswa sangat antusias melihat percobaan dan merasa tertarik dengan percobaan yang dilakukan. Banyak siswa yang maju ke depan kelas dan mengajukan beberapa pertanyaan tentang percobaan yang dilakukan. Siswa yang awalnya diam, tidak berani mengemukakan pendapat, mereka mulai berani berbicara dan aktif dalam pembelajaran. Terlihat dari banyaknya siswa yang ingin mencoba sendiri menggunakan alat peraga sederhana. Penggunaan alat peraga ini mengundang keingintahuan siswa terhadap peristiwa hukum Newton. Keingintahuan siswa muncul karena siswa menggangap bahwa pembelajaran dengan alat peraga sederhana dari barang bekas merupakan pembelajaran baru bagi mereka. Menurut siswa, pembelajaran dengan alat peraga sederhana dari barang bekas sebagai media pembelajaran yang menyenangkan. Dengan metode pembelajaran menggunakan model inkuiri terbimbing dengan alat peraga BARBEKU, siswa terlihat aktif dalam belajar sehingga minat belajar siswa tersebut memiliki pengaruh dalam belajar karena minat akan memberikan semangat dalam belajar siswa. Fakta empiris ini relevan dengan pendapat (Fitriana, 2020) bahwa, metode dalam proses pembelajaran dapat membentuk minat baru.

Data nilai hasil pretest posttest tersebut kemudian di uji normalitas menggunkan SPSS V.25. kedua kelas memiliki nilai signifikansi lebih dari 0,05, sehingga dapat disimpulkan bahwa data hasil penelitian kedua 
kelas tersebut terdistribusi normal. Setelah diketahui data terdistribusi normal, selanjutnya dilakukan uji homogenitas menggunakan SPSS V.25 untuk mengetahui kehomogenan kedua sampel. Berdasarkan uji tersebut, didapatkan nilai signifikansi lebih dari 0,05 sehingga kedua sampel dinyatakan homogen.

Data yang telah terbukti normal dan homogen kemudian dilanjutkan pada uji hipotesis dengan menggunakan uji independent sampel t-test. Berdasarkan uji tersebut kriteria keputusannya Jika nilai sig. > 0,05 maka HO diterima (tidak ada pengaruh) dan Jika nilai sig. < 0,05 H0 ditolak (ada pengaruh). Hal ini dapat diartikan bahwa terdapat pengaruh yang signifikan pada pemahaman konsep fisika siswa antara kelas yang di terapkan model pembelajaran inkuiri terbimbing dengan alat peraga barbeku dan model konvensional

Untuk mengetahui terdapat pengaruh yang signifikan antara model pembelajaran inkuiri terbimbing dengan alat peraga barbeku terhadap pemahaman konsep fisika siswa di kelas X MA Al-Islamiyah Blumbungan pada materi Hukum Newton, dapat dilohat pada Tabel 4.7 yang menunjukkan bahwa nilai sig. pemahaman konsep siswa adalah 0,000 , sehingga $\mathrm{H}_{0}$ ditolak karena nilai sig. $<0,05$ dan dinyatakan ada pengaruh yang signifikan pada model pembelajaran inkuiri terbimbing dengan alat peraga barbeku terhadap pemahaman konsep fisika siswa pada materi hukum newton. Hasil statistik menunjukkan bahwa model pembelajaran inkuiri terbimbing dengan alat peraga barbeku memberikan konstribusi positif terhadap pemahaman konsep fisika siswa. Dari penelitian tersebut dapat diambil kesimpulan bahwa ada perbedaan pada hasil pemahaman konsep antara siswa yang mengikuti pelajaran dengan model pembelajaran inkuiri terbimbing dengan model pembelajaran konvensional.

Pada proses pembelajaran dengan menggunakan model inkuiri terbimbing siswa dibimbing dalam merumuskan permasalahan, membuat hipotesis, merencanakan percobaan (Rais et al., 2020). Melakukan percobaan untuk memperoleh data, Mengumpulkan data dan menganalisis, dan Membuat kesimpulan (Kurniawati \& Diantoro, 2014). Tahap selanjutnya siswa dibimbing untuk mengetahui konsep yang prinsip kerjanya mirip dengan materi yang sedang dipelajari kemudian diberikan sebuah permasalahan dalam penerapan tersebut (Sinta, 2019). Pada tahap ini siswa mulai mengembangkan kemampuan berpikir kreatifnya dengan mengidentifikasi kemungkinan jawaban sementara yang diperoleh kemudian dilakukan percobaan untuk membuktikan hipotesis yang diajukan dengan melakukan perbobaan untuk memperoleh data, setelah data diperoleh maka data tersebut di analisis dengan menjawab sebuah pertanyaan yang sesuai dengan LKS serta ditarik sebuah kesimpulan untuk tahap terakhir. Pada tahap ini guru membagi siswa menjadi 3 kelompok untuk kemudian siswa mendiskusikan pemecahan masalah dengan anggota kelompoknya. Selanjutnya siswa berdiskusi merencanakan dan melakukan percobaan untuk membuktikan hipotesis dari permasalahan yang diperoleh pada materi hukum I, II, dan III Newton yang dilakukan dan mencatat hasilnya di LKS dan menganalisis data hasil percobaan. Lebih lanjut, indikator pemahaman konsep juga terfasilitasi pada tahapan Merangkum, menyimpulkan, membandingkan, dan menjelaskan, Pada tahap ini masing masing kelompok mempresentasikan hasil percobaan dan hasil diskusi didepan kelas kemudian guru bersama siswa melakukan refleksi terhadap kegiatan dan hasil percobaan dengan cara menanggapi atau menyanggah hasil diskusi pada kelompok yang sedang presentasi. Lebih lanjut pada tahap selanjutnya guru membimbing serta mengarahkan diskusi dan memberikan koreksi penguatan dan menyimpulkan mengenai materi hukum I, II, dan III Newton.

Model pembelajaran inkuiri terbimbing merupakan salah satu model pembelajaran yang digunakan untuk meningkatkan pemahaman konsep siswa (Isa, 2010). Hal ini ditunjukkan pada hasil perhitungan $\mathrm{N}$-gain yang menunjukkan peningkatan pemahaman konsep siswa pada kelas eksperimen sebesar 0,7655 dengan kategori tinggi. Sedangkan pada kelas kontrol besarnya peningkatan pemahaman konsep siswa sebesar 0,3885 dengan kategori sedang. Perbedaan peningkatan pemahaman konsep ini disebabkan oleh beberapa aktivitas berbeda yang terjadi pada kedua kelas selama proses pembelajaran berlangsung (Amijaya et al., 2018). Pada kegiatan pembelajaran kelas eksperimen siswa yang diajarkan menggunakan model inkuiri terbimbing sehingga dapat mengeksplorasi materi dan menemukan konsep atau prinsip, sedangkan pada kelas kontrol siswa hanya menerima informasi dari guru dan pembelajaran cenderung monoton. Sehingga hal tersebut mengakibatkan siswa kurang dapat memaknai materi yang dipelajari (Riani et al., 2021). Model inkuiri terbimbing adalah suatu model pembelajaran untuk menemukan sendiri pengetahuan dalam belajar (Wardani \& Setiawan, 2016). Siswa memperoleh pengetahuan yang sebelumnya belum diketahui tanpa pemberitahuan (Hariani \& Nuswowati, 2020), namun ditemukan sendiri oleh siswa karena dengan menemukan sendiri siswa dapat lebih mengerti materi secara mendalam (Maladjuna et al., 2017). Pengetahuan ditemukan sendiri ini dapat mempengaruhi hasil pemahaman konsep siswa meningkat (Maretasari \& Subali, 2013). Pada pembahasan 
diatas menunjukkan proses pembelajaran yang menggunakan model inkuiri terbimbing akan lebih efektif untuk meningkatkan pemahaman konsep siswa.

Berdasarkan analisis tersebut maka dapat disimpulkan bahwa terdapat pengaruh yang signifikan penggunaan model pembelajaran inkuiri terbimbing terhadap pemahaman konsep siswa. Kesimpulan ini diperkuat dengan hasil-hasil penelitian yang relevan dengan penelitian sebelumnya yaitu: penelitian yang dilakukan oleh (Tangkas, 2012), menemukan bahwa Pembelajaran Inkuiri Terbimbing dapat meningkatkan Kemampuan pemahaman konsep dan Keterampilan proses sains siswa dan penelitian lainnya yang dilakukan oleh (Abelta et al., 2017), menemukan bahwa Pembelajaran inkuiri terbimbing dapat meningkatkan hasil belajar melalui pemahaman konsep natar dan penelitian selanjutnya yang dilakukan oleh (Ngertini et al., 2013) menemukan bahwa Pembelajaran Inkuiri terbimbing dapat meningkatkan kemampuan pemahaman konsep dan literasi sains siswa. Bahwa penelitian mereka menunjukkan persentase pemahaman konsep siswa menunjukkan kenaikan setelah siswa mendapatkan model inkuiri Terbimbing.

\section{SIMPULAN}

Berdasarkan penelitian yang telah dilakukan, dapat disimpulkan bahwa: Model pembelajaran inkuiri terbimbing dengan alat peraga barbeku berpengaruh secara signifikan terhadap pemahaman konsep siswa pada materi hukum newton. Berdasarkan uji independent sample t-test, menunjukkan bahwa nilai signifikansi adalah 0,000 dan nilai tersebut lebih kecil dari probabilitas 0,05. Diketahui dalam pengujian ini menunjukkan bahwa $\mathrm{H} 1$ diterima dan $\mathrm{HO}$ ditolak. Yang artinya ada pengaruh yang signifikan pada model inkuiri terbimbing dengan alat peraga barbeku terhadap pemahaman konsep siswa pada materi hukum newton. Selain itu, peningkatan pemahaman konsep siswa pada materi hukum newton setelah menggunakan model inkuiri terbimbing dengan alat peraga barbeku berada pada kategori tinggi. Hal tersebut dapat dilihat dari hasil uji $\mathrm{N}$ Gain bahwa $g=0,7655$ dengan $g \geq 0,7$, maka pemahaman konsep siswa pada materi hukum newton setelah menggunakan model inkuiri terbimbing dengan alat peraga barbeku lebih tinggi dari pada sebelum menggunakan model inkuiri terbimbing dengan alat peraga barbeku.

Saran yang dapat diberikan terkait penelitian ini adalah model inkuiri terbimbing dengan alat peraga barbeku dapat digunakan sebagai variasi model pembelajaran. Sehingga membuat siswa aktif dan senang dalam mengikuti proses pembelajaran sedangkan, bagi peneliti selanjutnya, apabila ingin melakukan penelitian dengan judul yang sama akan diharapkan agar penelitian yang dilakukan lebih disempurnahkan lagi.

\section{Ucapan Terima Kasih}

Terimakasih diucapakan kepada sivitas akademika Universitas Islam Madura yang telah memberikan izin dan dukungan untuk melakukan penelitian ini dan perangkat sekolah yang telah bersedia dan membatu terlaksanannya kegiatan ini.sehingga kegiatan ini dapat terlaksana dengan sukses.

\section{Daftar Pustaka}

Abelta, G. A., Ertikanto, C., \& Wahyudi, I. (2017). Pengaruh Penggunaan LKS Berbasis Inkuiri Terbimbing Terhadap Hasil Belajar Melalui Pemahaman Konsep.

Amijaya, L. S., Ramdani, A., \& Merta, I. W. (2018). Pengaruh Model Pembelajaran Inkuiri Terbimbing Terhadap Hasil Belajar Dan Kemampuan Berpikir Kritis Peserta Didik. Jurnal Pijar Mipa, 13(2), 94. https://doi.org/10.29303/jpm.v13i2.468

Arends, R. (2012). Learning to teach 9th edition. New York: the mcgraw hill companies.

Bern, R., \& Erickson, P. (2001). Contextual theaching and learning. Journal of research.

Fitriana, N. (2020). Optimalisasi Pemahaman Fisika Pada Hukum Newton Dengan Inquiry-Heuristik Vee Berbantuan Alat Peraga. JURNAL PENDIDIKAN SAINS (JPS), $8(1), 73$. https://doi.org/10.26714/jps.8.1.2020.73-80

Gardner, H. (1999). Disciplined Mind: What All Students Should Understand. New York: simon and schuster. 
Hariani, N. R., \& Nuswowati, M. (2020). Pengaruh Penerapan Model Inkuiri Terbimbing Berbantuan E-Modul Terhadap Pemahaman Konsep Inkuiri Garam. 14(1), 11. https://doi.org/10.15294/jipk.v14i1.21553

Herimanto, H., Murdani, E., \& Kurniawan, Y. (2018). Penerapan Model Pembelajaran Inkuiri Terbimbing Untuk Meningkatkan Pemahaman Konsep Siswa Kelas VII Pada Materi Pengukuran. JIPF (Jurnal Ilmu Pendidikan Fisika), 3(2), 44. https://doi.org/10.26737/jipf.v3i2.577

Isa, A. (2010). Keefektifan Pembelajaran Berbantuan Multimedia Menggunakan Metode Inkuiri Terbimbing Untuk Meningkatkan Minat Dan Pemahaman Siswa. 5. https://doi.org/10.15294/jpfi.v6i1.1105

Kurniawati, I. D., \& Diantoro, M. (2014). Pengaruh Pembelajaran Inkuiri Terbimbing Integrasi Peer Instruction Terhadap Penguasaan Konsep Dan Kemampuan Berpikir Kritis Siswa. 11. https://doi.org/10.15294/jpfi.v10i1.3049

Maladjuna, D. A., Saehana, S., \& Syamsu, S. (2017). Pengaruh Model Pembelajaran Inkuiri Terbimbing Terhadap Pemahaman Konsep Siswa pada Mata Pelajaran Fisika di SMP Negeri 19 Palu. JPFT (Jurnal Pendidikan Fisika Tadulako Online), 5(1), 7. https://doi.org/10.22487/j25805924.2017.v5.i1.7126

Maretasari, E., \& Subali, B. (2013). Penerapan Model Pembelajaran Inkuiri Terbimbing Berbasis Laboratorium Untuk Meningkatkan Hasil Belajar Dan Sikap Ilmiah Siswa. 5. https://doi.org/10.15294/upej.v1i2.1375

Masturoh, R. D., Sudarmi, M., \& Noviandini, D. (2019). Barang Bekas di Sekitarku (BARBEKU) Sebagai Alat Peraga Sederhana Untuk Meningkatkan Pemahaman Hukum III Newton. Jurnal Sains dan Edukasi Sains, 2(1), 16-25. https://doi.org/10.24246/juses.v2i1p16-25

Ngertini, N. N., Prof. Dr I Wayan Sadia, M. P., \& Prof. Dr. I Made Yudana, M. P. (2013). Pengaruh Implementasi Model Pembelajaran Inkuiri Terbimbing Terhadap Kemampuan Pemahaman Konsep Dan Literasi Sains Siswa Kelas X SMA PGRI 1 Amlapura. Jurnal Administrasi Pendidikan Indonesia, 4(1), Article 1. https://doi.org/10.23887/japi.v4i1.1012

Rais, A. A., Hakim, L., \& Sulistiawati, S. (2020). Pemahaman Konsep Siswa melalui Model Inkuiri Terbimbing Berbantuan Simulasi PhET. Physics Education Research Journal, 2(1), 1. https://doi.org/10.21580/perj.2020.2.1.5074

Riani, L., Misdalina, M., \& Sugiarti, S. (2021). Peningkatan Pemahaman Konsep Siswa Menggunakan Inkuiri Terbimbing Berbantuan Edmodo. Jurnal Luminous: Riset Ilmiah Pendidikan Fisika, 2(1), 17. https://doi.org/10.31851/luminous.v2i1.5237

Siahaan, K. W. A., Lumbangaol, S. T. P., Marbun, J., Nainggolan, A. D., Ritonga, J. M., \& Barus, D. P. (2020). Pengaruh Model Pembelajaran Inkuiri Terbimbing dengan Multi Representasi terhadap Keterampilan Proses Sains dan Penguasaan Konsep IPA. Jurnal Basicedu, 5(1), 195-205. https://doi.org/10.31004/basicedu.v5i1.614

Sinta, T. (2019). Penerapan Model Pembelajaran Inkuiri Terbimbing Berbentuk Augmented Reality pada Peserta Didik untuk Meningkatkan Minat dan Pemahaman Konsep IPA. 12. https://doi.org/10.15294/upej.v8i2.33309

Sugiono. (2017). Metode penelitian pendidikan pendekatan kuantitatif, kualitatif, dan REDD. Bandung: alfabeta.

Suyanti, R. (2010). Strategi pembelajaran kimia. Yogyakarta: graha ilmu.

Tangkas, I. M. (2012). Pengaruh Implementasi Model Pembelajaran Inkuiri Terbimbing Terhadap Kemampuan Pemahaman Konsep Dan Keterampilan Proses Sains Siswa Kelas X SMAN 3 Amlapura. Jurnal Pendidikan Dan Pembelajaran IPA Indonesia, 2(1), Article 1. https://ejournalpasca.undiksha.ac.id/index.php/jurnal_ipa/article/view/410

Trianto. (2011). Mendesain model pembelajaran inovatif-progresif. jakarta: kencana prenada.

Wardani, S., \& Setiawan, S. (2016). Pengaruh Pembelajaran Inkuiri Terbimbing Terhadap Pemahaman Konsep Dan Oral Activities Pada Materi Pokok Reaksi Reduksi Dan Oksidasi. 10(2), 8. https://doi.org/10.15294/jipk.v10i2.9527 